\title{
Detecting Climate Change in Using Extreme Data from Two Surface Weather Stations: Case Study Valle of Comitan and La Esperanza, Chiapas, Mexico
}

\author{
Martín Mundo-Molina, Eber A. Godinez-Gutiérrez, José Luis Pérez-Díaz, \\ Daniel Hernández-Cruz \\ Investigation Centre, Faculty of Engineer Autonomous, University of Chiapas, Chiapas, Mexico \\ Email:martin.mundo@unach.mx
}

How to cite this paper: Mundo-Molina, M., Godinez-Gutiérrez, E.A., Pérez-Díaz, J.L. and Hernández-Cruz, D. (2021) Detecting Climate Change in Using Extreme Data from Two Surface Weather Stations: Case Study Valle of Comitan and La Esperanza, Chiapas, Mexico. Journal of Water Resource and Protection, 13, 1061-1075.

https://doi.org/10.4236/jwarp.2021.1312057

Received: November 20, 2021

Accepted: December 21, 2021

Published: December 24, 2021

Copyright $\odot 2021$ by author(s) and Scientific Research Publishing Inc. This work is licensed under the Creative Commons Attribution International License (CC BY 4.0).

http://creativecommons.org/licenses/by/4.0/

\begin{abstract}
The study area is located between the cities of Comitan $\left(16^{\circ} 10^{\prime} 43^{\prime \prime} \mathrm{N}\right.$ and $\left.92^{\circ} 04^{\prime} 20^{\prime \prime} \mathrm{W}\right)$ a city with 150,000 inhabitants and La Esperanza $\left(16^{\circ} 9^{\prime} 15^{\prime \prime} \mathrm{N}\right.$ and $\left.91^{\circ} 52^{\prime} 5^{\prime \prime} \mathrm{W}\right)$ a town with 3000 inhabitants. Both weather stations are $30 \mathrm{~km}$ from each other in the Chiapas State, México. 54 years of daily records of the series of maximum $\left(t_{\max }\right)$ and minimum temperatures $\left(t_{\min }\right)$ of the weather station 07205 Comitan that is on top of a house and 30 years of daily records of the weather station $07374 \mathrm{La}$ Esperanza were analyzed. The objective is to analyze the evidence of climate change in the Comitan valley. $2.07 \%$ and $19.04 \%$ of missing data were filled, respectively, with the WS method. In order to verify homogeneity three methods were used: Standard Normal Homogeneity Test (SNHT), the Von Neumann method and the Buishand method. The heterogeneous series were homogenized using climatol. The trends of $t_{\max }$ and $t_{\min }$ for both weather stations were analyzed by simple linear regression, Sperman's rho and Mann-Kendall tests. The Mann-Kendal test method confirmed the warming trend at the Comitan station for both variables with $Z_{M K}$ statistic values equal to 1.57 (statistically not significant) and 4.64 (statistically significant). However, for the Esperanza station, it determined a cooling trend for $t_{\min }$ and a slight non-significant warming for $t_{\max }$ with a $Z_{M K}$ statistic of -2.27 (statistically significant) and 1.16 (statistically not significant), for a significance level $\alpha=0.05$.
\end{abstract}

\section{Keywords}

Climate Change, Climatic Variability, Temperature Trends, Time Series 


\section{Introduction}

The natural climatic variability of the Earth has always existed. From this perspective, climate change or global warming is not new since it dates from geological times. Paleoclimatology gives accounts of this process by means of diverse techniques. One technique is the impressions created by the climatic factors in remote times by means of the proxies like diatoms, foraminifers, corals, ice and of some sedimentary rock cores, tree rings [1] and lake, lagoon and wetlands sediments [2]. During the last 5000 years the Earth has had strong oscillations of heating and cooling [1] generated by natural processes; however, at present the most accepted hypothesis about the climatic instability of the Earth is that global warming is due to anthropogenic actions. The objective is to analyze the evidence of climate change in the Comitan valley and point out the methodological errors that are committed. It was studied of 54 and 30 years of the weather stations 07205 Comitan and 07374 La Esperanza, located within the Grijalva-Usumacinta, Mexico hydrological region (HR) in the context of natural or anthropogenic climatic instability.

The region to which the study area (SA) belongs is temperate and is located at an approximate altitude of 1550 mamsl, with average temperatures that vary between $16^{\circ} \mathrm{C}$ and $18^{\circ} \mathrm{C}$. Precipitation is from 2000 to $2500 \mathrm{~mm} /$ year. The orography is abrupt, and together with the climate allows for the existence of diverse types of forests (conifers, mountain mesophiles and oaks) and induced vegetation [3]. The $\mathrm{SA}$ is a flat agricultural valley located between the cities of Comitan $\left(16^{\circ} 10^{\prime} 43^{\prime \prime} \mathrm{N}\right.$ and $\left.92^{\circ} 04^{\prime} 20^{\prime \prime} \mathrm{W}\right)$ and La Esperanza $\left(16^{\circ} 9^{\prime} 15^{\prime \prime} \mathrm{N}\right.$ and $\left.91^{\circ} 52^{\prime} 5^{\prime \prime} \mathrm{W}\right)$, Chiapas, Mexico. In this valley there are two standard weather stations, La Esperanza (07374) and Comitan (07205), both within the Technified Rainfed Agricultural District 011 (DDT 011, by its Spanish acronym) which has an approximate area of 30,000 hectares (Figure 1). The area of influence of both stations is approximately 12,000 hectares, due to the orography of the SA. Within the limits of DTT 011, anthropogenic alteration has modified the natural vegetation and the forest has been deforested and replaced by agricultural crops [4] by the slow but permanent

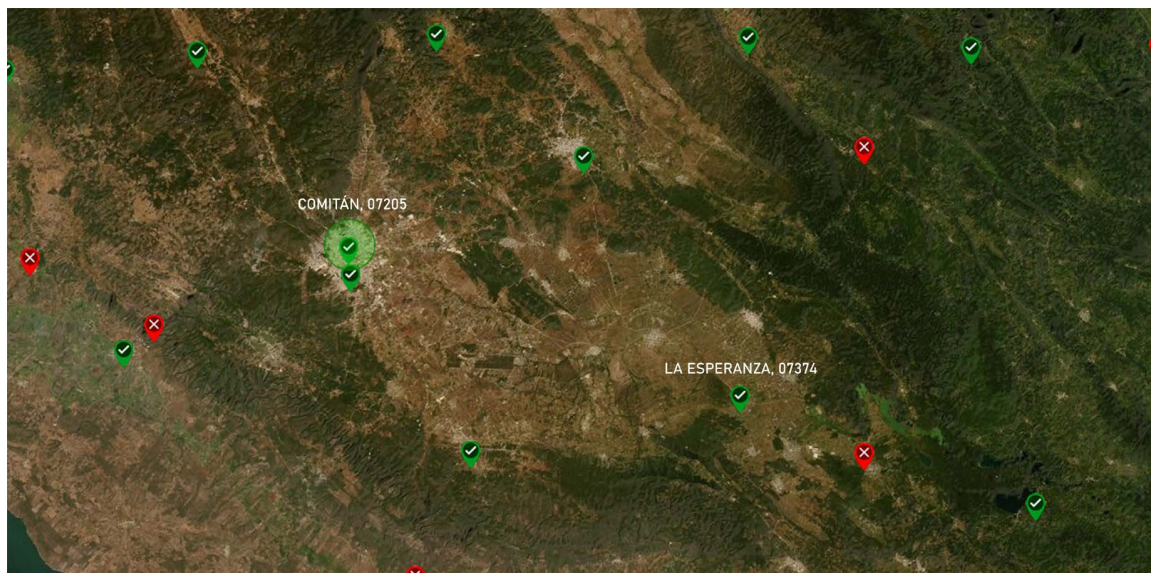

Figure 1. Weather stations: Comitan and La Esperanza. 
urbanization in the last 5 decades in this agricultural valley. Currently in the SA there is a wide variety of secondary vegetation and agricultural crops.

There are not many studies related to climatic change in the Comitan valley. Although the results presented by [5] are the product of global models, a mesoscale study by [6] was found that includes not only the SA but also the 07205 Comitan weather station. Alonso [6] studied the climate change indices in the Rio Grande watershed of Chiapas, specifically the sub-watershed RD30Gl-Río Grande Comitan that has an area of $6212.51 \mathrm{~km}^{2}$. The indices were calculated from "...the series of observed data of temperatures (maximum and minimum) and precipitation of a period of more than 50 years in three weather stations of which two had a statistically significant tendency in six indexes related to air temperature; both stations show an increasing trend in summer days (SU25), extreme maximum temperature (TXx), frequency of hot days (Tx90p) and daytime temperature range (DTR). Alonso [6] concludes in the study that "...the minimum and maximum temperatures have a significant upward trend at stations 07205 (Comitan) and 07104 (Las Margaritas), the number of days in a year when the maximum temperature is higher than $25^{\circ} \mathrm{C}$, has had an increase of 2743 and 2816 days/year, the maximum annual value of the maximum daily temperature has increased by $0.047^{\circ} \mathrm{C} /$ year and $0.109^{\circ} \mathrm{C} /$ year, and an annual average of the difference between maximum temperature and minimum temperature increments of $0.028^{\circ} \mathrm{C} /$ year and $0.054^{\circ} \mathrm{C} /$ year". However, the study is weak. The methodology used and its conclusions are hasty and lack scientific rigor for the following reasons: 1) It is not possible to obtain surface atmospheric temperature trends of only three weather stations for such a large area as the sub-watershed RD30Gl-Río Grande Comitan. It is an unacceptable generalization; 2) The climate of the sub-basin is very varied due to its orography, with heights above sea level ranging from $160 \mathrm{~m}$ to $2614 \mathrm{~m}$, therefore there are multiple micro-climates in the study area generated by abrupt hills, the presence of large bodies of water such as lakes, rivers, and streams, and there are valleys, canyons and large areas in the process of deforestation; 3) According to [7] a network of dispersed weather stations is insufficient for the study of the maximum and minimum temperature of an area. A very dense network is needed to examine the climatology of precipitation, wind, frost and fog, especially in regions of steep topography [7] such as the sub-watershed RD30Gl-Río Grande Comitan; 4) The influence of a weather station to measure the air temperature in many areas of the sub-watershed RD30Gl-Río Grande Comitan, does not go beyond 10 $\mathrm{km}$ which is equivalent to an area of $78.5 \mathrm{~km}^{2}$, as in the case of the station 07295 Comitan; 5) According to [8] the horizontal meteorological scale of the [6] should be the mesoscale, however only three weather stations were studied (at least one of them with local meteorological scale scopes) to obtain their conclusions; 6) The methodology of [6] is enunciative but not demonstrative, because it does not indicate the percentage of filled data or its temporality. The method used to homogenize the series is also enunciated and the tests " $\mathrm{t}$ " and "F" are only used alone without taking into account one of the most relevant tests: The Standard Normal Homogeneity Test (SNHT); 7) On the other hand, within the methodology described in [6] there is no description of what percentage of 
data were missing from the studied time series and it does not state or describe the method used to fill in missing data; 8) It tacitly conveys the idea that the maximum and minimum temperatures of the three stations are a homogeneous time series, however at least one of them is not. Weather station 07205 data is heterogeneous, that is, the maximum and minimum temperatures have significant changes due to alterations in the environment where it is located as demonstrated in [9]; 9) The results and conclusions of [6] change if the data of the 07205 Comitan weather station is homogenized; 10) Finally, the aforementioned document states that the minimum and maximum temperatures show a significant upward trend that shows a coincidence with what was predicted for the state of Chiapas as reported by [5]. This is a wrong argument for the meteorological scales: the results presented in [5] are on a synoptic scale and the stations which were analyzed are on a local scale.

\section{Material and Methods}

\subsection{Temporal Series: Data Filling (WS Method)}

Data missing from temporal series. Temporal temperature series generally present missing data that limit their use. Before analyzing anomalies, cyclic cooling-heating processes or trends, it is necessary to know the amount of missing data. According to [7] it is recommended to not calculate a monthly value if more than 10 daily values are missing (33\% of the monthly information). On the other hand, in [10] a stricter criterion is suggested for establishing the limit of 5 missing days per month (17\% of the information). For the norms or means of a period, it is suggested that there are at least $80 \%$ of the registered years and there should be no missing values for more than three consecutive years [7]. The temporal series of weather station 07205 Comitan has a record of 54 years of daily temperature data, from 1961 to 2014 , with $2.7 \%$ of the data missing. The temporal series for weather station $07374 \mathrm{La}$ Esperanza has a record of 30 years of daily temperature data, from 1984 to 2013, with $19.04 \%$ of data missing. The percentage of missing data from the Comitan weather station is below all of the criteria stated by [7], while La Esperanza meets two of the three criteria mentioned above. These data have been duly filled in with the methods explained in the following section.

Filling of data. In order to use meteorological data with a certain level of confidence, historical records are required to be continuous to reduce the risk of error and avoid bias in the results [11]. According to [12], [7] proposes the following statistical methods for the filling of missing data: simple linear regression (LR), multiple regressions (MR), ratio $q$ and normal-ratio $q(\mathrm{NR})$. Thus, [12] conducted a study which objective was to determine the reliability of four filling methods: The U.S. National Weather Service (WS), deductive reasoning (DR), multiple regression (MR) and LR. In order to fulfill this purpose, they analyzed the series of precipitation and the maximum and minimum temperature of seven weather stations located in the northern zone of 
the banana axis of Urabá Antioqueño in Colombia, in the period from 2006 to 2009. They concluded that the WS method has minimum squared errors similar to the other methods for precipitation and maximum and minimum temperature that were studied. For this reason, they used this method for the filling of the missing data for the 7 weather stations, since the LR and MR methods had low determination coefficients. A similar case was presented at weather stations 07502 Comitan and 07374 La Esperanza, which is why the WS method was used to fill in the missing data.

WS method. The WS method considers that the missing data of the weather station " $A$ " can be estimated based on the surrounding weather stations, weighting the observed values in a quantity $\mathrm{W}$ equal to the reciprocal of the square of the distance $(d)$ between each neighboring weather station and the " $\mathrm{A}$ " weather station. The missing data $\left(P_{X}\right)$ sought will be equal to [13]:

$$
P_{X}=\sum \frac{\left(P_{i}\right)\left(W_{i}\right)}{W_{i}}
$$

where:

$P_{i}=$ Data observed on the missing date in the surrounding auxiliary weather stations.

$W_{i}=\frac{1}{d_{i}^{2}}, d_{i}$ is the distance between each surrounding weather station with respect to the incomplete station.

It is evident that the WS method requires nearby weather stations in order to make data filling more efficient. The auxiliary weather stations used for weather station 07205 Comitan and $07374 \mathrm{La}$ Esperanza are shown in Table 1 and Table 2 , while the $W_{i}$ values are shown in Table 3 and Table 4 respectively.

With the data of the auxiliary stations of Table 1 and Table 2 and the values of Table 3 and Table 4, the missing daily data $\left(P_{X}\right)$ of both weather stations supported in Equation (1) were estimated.

\subsection{Homogeneity}

A temporal series of temperature may be inhomogeneous if there are instrumental

Table 1. Auxiliary weather stations for weather station 07205 Comitan.

\begin{tabular}{ccccccc}
\hline Code & Province & Name & Latitude & Longitude & $\begin{array}{c}\text { Altitude } \\
(\mathrm{msnm})\end{array}$ & $\begin{array}{c}\text { Distance } \\
(\mathrm{km})\end{array}$ \\
\hline 07205 & Comitan & Comitan (DGE) & 16.2511 & 92.1342 & 1630 & ----- \\
07062 & Las Margaritas & Finca la Soledad & 16.3881 & 91.8626 & 1469 & 32.79 \\
07055 & Las Margaritas & Finca Chayabe & 16.3814 & 91.7106 & 1596 & 47.52 \\
07104 & Las Margaritas & Las Margaritas & 16.3106 & 91.9747 & 1512 & 18.3 \\
07190 & La Trinitaria & La Trinitaria (CFE) & 16.1178 & 92.0517 & 1540 & 17.2 \\
07331 & Las Rosas & Villa las Rosas & 16.3672 & 92.3692 & 1300 & 28.2 \\
07391 & Las Margaritas & Yasha & 16.3903 & 92.0760 & 1750 & 16.7 \\
\hline
\end{tabular}


Table 2. Auxiliary weather stations for weather station 07374 La Esperanza.

\begin{tabular}{ccccccc}
\hline Code & Province & Name & Latitude & Longitude & $\begin{array}{c}\text { Altitude } \\
(\mathrm{msnm})\end{array}$ & $\begin{array}{c}\text { Distance } \\
(\mathrm{km})\end{array}$ \\
\hline 07374 & La Trinitaria & La Esperanza & 16.1542 & 91.8681 & 1500 & ----- \\
07062 & Las Margaritas & Finca la Soledad & 16.3881 & 91.8626 & 1469 & 26.04 \\
07055 & Las Margaritas & Finca Chayabe & 16.3814 & 91.7106 & 1596 & 30.48 \\
07104 & Las Margaritas & Las Margaritas & 16.3106 & 91.9747 & 1512 & 20.8 \\
07205 & Comitan & Comitan (DGE) & 16.2511 & 92.1342 & 1,630 & 30.42 \\
\hline
\end{tabular}

Table 3. $W_{i}$ values for each surrounding weather station (07205 Comitan).

\begin{tabular}{cc}
\hline Weather Station & $W_{i}=1 / d_{i}^{2} \quad\left(\mathbf{k m}^{2}\right)$ \\
\hline Finca la Soledad & 0.000930073 \\
Finca Chayabe & 0.00044284 \\
Las Margaritas & 0.002986055 \\
La Trinitaria (CFE) & 0.003380206 \\
Villa las Rosas & 0.001257482 \\
Yasha & 0.003585643 \\
\hline
\end{tabular}

Table 4. $W_{i}$ values for each surrounding weather station (07374 La Esperanza).

\begin{tabular}{cc}
\hline Weather Station & $W_{i}=1 / d_{i}^{2} \quad\left(\mathbf{k m}^{2}\right)$ \\
\hline Finca la Soledad & 0.00147475 \\
Finca Chayabe & 0.00107639 \\
Las Margaritas & 0.00231139 \\
Comitan (DGE) & 0.00108064 \\
\hline
\end{tabular}

measurement errors, errors in the coding of the data, changes in the observation procedure (for example, the time of observation), changes in the types of instruments or changes in their location over time [7] [14].

The homogeneity of temperature time series is very important because it allows for the detecting of variations and trends of the series in a reliable way. Thus, in a set of homogeneous climatic data, all of the fluctuations contained in its temporal series reflect the reliable variability and change of the represented climate element [7].

According to [14], other causes that can provoke a meteorological series to be heterogeneous are the variation of the climate due to deforestation, the construction of a dam, forest fires or climatic changes at a local or regional scale. In the event that a meteorological series is heterogeneous and cannot be homogenized, it is recommended that it is discarded.

Three methods were used to verify the homogeneity of the time series of maximum, average and minimum daily temperature of the two weather stations: 
Standard Normal Homogeneity Test (SNHT), the Von Neumann method and the Buishand method. When applying the three tests the series were heterogeneous, therefore it was necessary to apply several homogenization techniques.

The SNHT test is explained as an example. This test assumes a null hypothesis, where the values of the examined variable are independent and identically distributed (homogeneous). The alternate hypothesis assumes that there is a date on which there is a change in the average of the data. Thus, if $Q$ is the average and $Q_{i}$ the annual series to be examined ( $i$ is the year) and $S$ is the standard deviation, then the statistical test $T(k)$ is [15]:

$$
T(k)=k \bar{z}_{1}^{2}+(n-k) \bar{z}_{2}^{2}, k=1, \cdots, n
$$

where:

$$
\begin{gathered}
\bar{Z}_{1}=\frac{1}{k} \sum_{i=1}^{k} \frac{Q_{i}-\bar{Q}}{S} \\
\bar{Z}_{2}=\frac{1}{n-k} \sum_{i=k+1}^{k} \frac{Q_{i}-\bar{Q}}{S}
\end{gathered}
$$

The average of the first $k$ years and the last $n-k$ years of the record are compared. The variable $T(k)$ reaches its maximum value when there is a point of change located in year $k$. The $T(k)$ distribution of the series can be observed by plotting the results of each year. The test statistic $T_{0}$ is defined as:

$$
T_{0}=\max T(k), 1 \leq k \leq n
$$

If $T_{0}$ is greater than the critical value, the null hypothesis will be rejected. The critical values depend on the size of the sample (Table 5).

The heterogeneous series of maximum and minimum temperatures were homogenized using nine auxiliary weather stations surrounding Comitan weather station 07205 (shown in Table 6) using climatol software [17]. The series of homogenized $t_{\max }$ and $t_{\min }$ are shown as an example in Figure 2 and Figure 3.

\section{Results}

In this study, simple linear regression was used to detect climate change trends in the Comitan and La Esperanza weather stations. Simple linear regressions are shown in Figure 2 and Figure 3. Figure 2 of the Comitan weather station shows an increase in temperature, while Figure $3 \mathrm{La}$ Esperanza shows an increase $t_{\max }$ but without significance, nevertheless the $t_{\min }$ decreases. However, the simple linear regression does not represent any statistical analysis, for these reasons Spearman's rho and Mann Kendall test were used.

Spearman's rho $(S R)$. The SR test is a simple method with uniform power for

Table 5. $T_{0}$ depending on the size of the sample [16].

\begin{tabular}{ccccccc}
\hline$N$ & 20 & 30 & 40 & 50 & 70 & 100 \\
\hline $1 \%$ & 9.56 & 10.45 & 11.01 & 11.38 & 11.89 & 12.32 \\
$5 \%$ & 6.95 & 7.65 & 8.10 & 8.45 & 8.80 & 9.15 \\
\hline
\end{tabular}


Table 6. Surrounding auxiliary weather stations used for weather station 07205.

\begin{tabular}{|c|c|c|c|c|c|c|}
\hline Code & Province & Name & Latitude & Longitude & $\begin{array}{l}\text { Altitude } \\
\text { (msnm) }\end{array}$ & $\begin{array}{c}\text { Distance } \\
(\mathrm{km})\end{array}$ \\
\hline 07205 & Comitan & Comitan (DGE) & 16.2511 & 92.1342 & 1630 & ----- \\
\hline 07037 & La Concordia & Finca Cuxtepeques & 15.7286 & 92.9689 & 1550 & 105.07 \\
\hline 07055 & Las Margaritas & Finca Chayabe & 16.3814 & 91.7106 & 1596 & 49.06 \\
\hline 07040 & Ixtapa & El Burrero & 16.7892 & 92.8283 & 1544 & 95.12 \\
\hline 07057 & Tapachula & Finca Chicharras & 15.1331 & 92.0517 & 1540 & 124.09 \\
\hline 07015 & Bochil & Bochil & 16.9864 & 92.8914 & 1200 & 114.31 \\
\hline 07006 & Altamirano & Altamirano (SMN) & 16.7392 & 92.0378 & 1240 & 55.06 \\
\hline 07048 & Escuintla & Finca el Triunfo & 15.3481 & 92.5486 & 822 & 109.39 \\
\hline 07009 & $\begin{array}{l}\text { Frontera } \\
\text { Comalapa }\end{array}$ & Aquespala & 15.7942 & 91.9203 & 617 & 55.7 \\
\hline 07039 & Suchiapa & El Boquerón & 16.6442 & 93.1572 & 500 & 117.38 \\
\hline
\end{tabular}

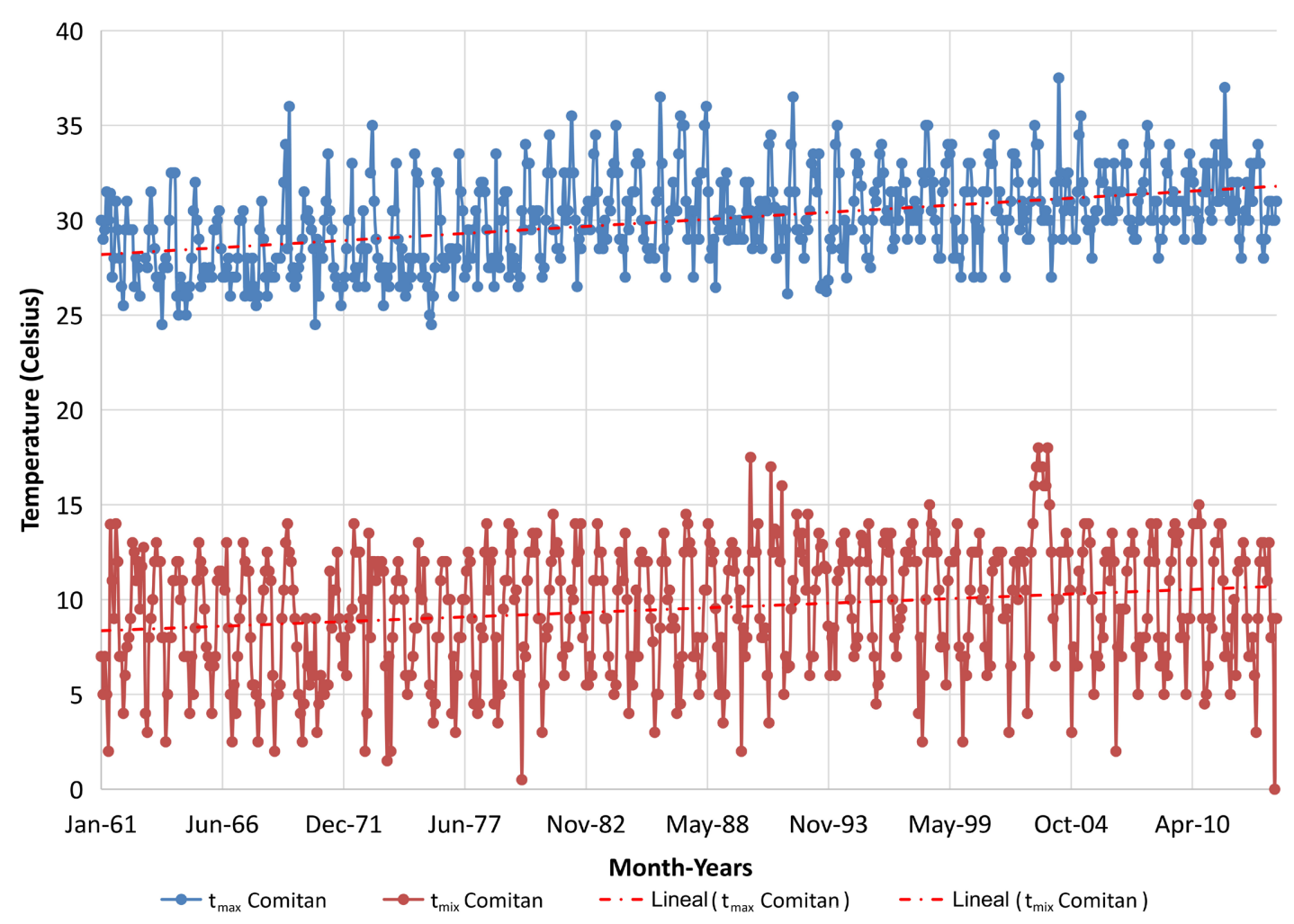

Figure 2. Homogeneous series, $t_{\max }$ and $t_{\min }$, weather station Comitán.

linear and non-linear trends and is commonly used to verify the absence of trends [18] [19]. In this test, the null hypothesis $\left(\mathrm{H}_{0}\right)$ is that all the data in the time series are independent and identically distributed, while the alternative hypothesis $\left(\mathrm{H}_{1}\right)$ is that increasing or decreasing trends exist [20]. The SR test statistic $D$ and the standardized test statistic $Z_{S R}$ are expressed as follows [21] [22]: 


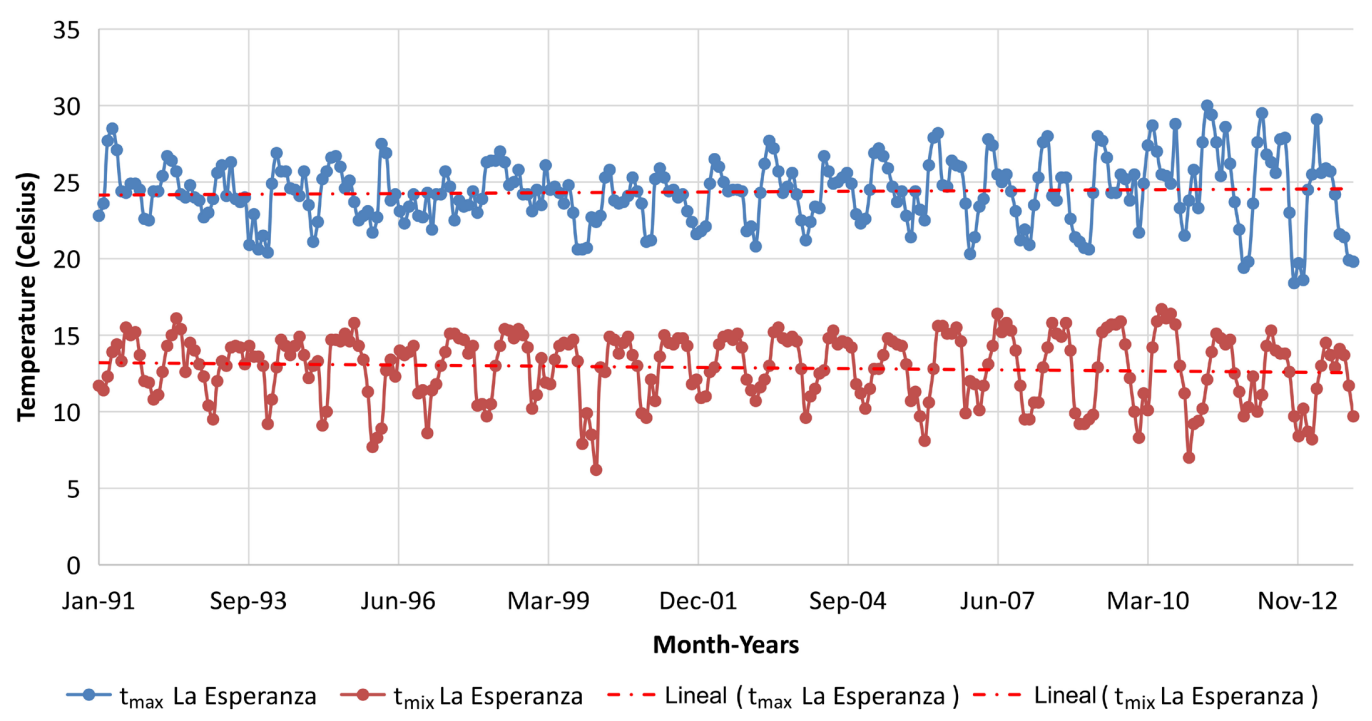

Figure 3. Homogeneous series, $t_{\max }$ and $t_{\min }$, weather station La Esperanza.

$$
\begin{gathered}
D=1-\frac{6 \sum_{i=1}^{n}\left(R_{i}-i\right)^{2}}{n\left(n^{2}-1\right)} \\
Z_{S R}=D \sqrt{\frac{n-2}{1-D^{2}}} \\
\beta=\text { Median }\left[\frac{X_{j}-X_{i}}{j-1}\right] \text { for all } i<j
\end{gathered}
$$

where $R_{i}$ is the rank of its observation $X_{i}$ in the time series and $n$ is the length of the time series. Positive values of $Z_{S R}$ indicate upward trends, while negative $Z_{S R}$ indicates downward trends in the time series. When $Z_{S R}>t_{n-2,1-\alpha}$; the null hypothesis is rejected and a significant trend exists in the time series. $t_{n-2,1-\alpha / 2}$ is the critical value of $t$ from the $t$-student table, for 5\% significant level [22]. Spearman's rho correlation values are shown in Table 7 [21].

Table 7 shows a moderate correlation for the Comitan weather station. The rest of the variables have weak and inappropriate correlation as can be seen in Table 8. For that reason, the coefficient Spearman's rho was not taken into account in this investigation.

The Mann-Kendall test (MKT). [23] considers that the MKT test is the most appropriate method to analyze trends in climatological series. The MKT is a rank nonparametric test that was developed by [24] and [25], and it is superior for detecting linear or non-linear trends. In this test, the null $\left(\mathrm{H}_{0}\right)$ and alternative hypotheses $\left(\mathrm{H}_{1}\right)$ are equal to the non-existence and existence of a trend in the time series of the observational data, respectively. The related equations for calculating the MKT statistic $S$ and the standardized test statistic $Z_{M K}$ are as follows [22] [26] (Table 9):

$$
S=\sum_{i=1}^{n-1} \sum_{j=i+1}^{n} \operatorname{sgn}\left(X_{j}-X_{1}\right)
$$


Table 7. Coefficient $D$ of Spearman's rho.

\begin{tabular}{cc}
\hline $\begin{array}{c}\text { Conventional approach to interpreting a correlation } \\
\text { Coefficient, } D\end{array}$ & $D$ \\
\hline Very strong correlation & 1 \\
Strong correlation & $0.9<D<1$ \\
Moderate correlation & $0.8<D<0.9$ \\
Weak correlation & $0.5<D<0.8$ \\
Negligible & $D<0.5$ \\
\hline
\end{tabular}

Table 8. Summary of results.

\begin{tabular}{|c|c|c|}
\hline \multicolumn{3}{|c|}{ Simple linear regression } \\
\hline $\begin{array}{c}\text { Weather } \\
\text { station } / t_{\max } \text { y } t_{\min }\end{array}$ & $t_{\max }$ & $t_{\min }$ \\
\hline Comitan & $\begin{array}{l}\text { The maximum temperature has } \\
\text { increased } 3.8 \text { degrees Celsius in } 40 \\
\text { years. This will not be significant in } \\
\text { tests like Mann Kendall's. }\end{array}$ & $\begin{array}{l}\text { The minimum temperature has } \\
\text { increased } 2.4 \text { degrees Celsius in } 40 \\
\text { years. This will not be significant } \\
\text { in tests like Mann Kendall's. }\end{array}$ \\
\hline La Esperanza & $\begin{array}{l}\text { The maximum temperature has } \\
\text { increased } 0.4 \text { degrees Celsius in } 22 \\
\text { years. This will not be significant in } \\
\text { tests like Mann Kendall's. }\end{array}$ & $\begin{array}{l}\text { The minimum temperature has } \\
\text { decreased } 0.65 \text { degrees Celsius in } \\
22 \text { years. This will not be significant } \\
\text { in tests like Mann Kendall's. }\end{array}$ \\
\hline \multicolumn{3}{|c|}{ Spearmen's rho } \\
\hline & $t_{\max }$ & $t_{\min }$ \\
\hline Comitan & $D=-0.84$ & $D=-0.63$ \\
\hline La Esperanza & $D=-0.56$ & $D=-0.71$ \\
\hline \multicolumn{3}{|c|}{ Mann Kendall } \\
\hline & $t_{\max }$ & $t_{\min }$ \\
\hline Comitan & $Z_{M K}=1.57$ & $Z_{M K}=4.64$ \\
\hline La Esperanza & $Z_{M K}=1.16$ & $Z_{M K}=-2.27$ \\
\hline
\end{tabular}

Table 9. Description of the significance of the Mann-Kendall test [26].

\begin{tabular}{cc}
\hline Concept & $Z_{M K}$ \\
\hline No trend & 0 \\
Statistically significant increasing trends & $>+1.96$ \\
Statistically significant decreasing trends & $<-1.96$ \\
Statistically no significant increasing trends & $<+1.96$ \\
Statistically no significant decreasing trends & $>-1.96$ \\
\hline
\end{tabular}

$$
\operatorname{sgn}\left(X_{j}-X_{i}\right)= \begin{cases}+1 & \text { if }\left(X_{j}-X_{i}\right)>0 \\ 0 & \text { if }\left(X_{j}-X_{i}\right)=0 \\ -1 & \text { if }\left(X_{j}-X_{i}\right)<0\end{cases}
$$




$$
\begin{gathered}
\operatorname{Var}(S)=\frac{1}{18}\left[n(n-1)(2 n+5)-\sum_{p=1}^{q} t_{p}\left(t_{p}-1\right)\left(2 t_{p}+5\right)\right] \\
Z_{M K}= \begin{cases}\frac{S-1}{\sqrt{\operatorname{Var}(S)}} & \text { if } S>0 \\
0 & \text { if } S=0 \\
\frac{S+1}{\sqrt{\operatorname{Var}(S)}} & \text { if } S<0\end{cases}
\end{gathered}
$$

where $X_{i}$ and $X_{j}$ are the sequential data values of the time series in the years $i$ and $j, n$ is the length of the time series, $t_{p}$ is the number of ties for the $p$ th value, and $q$ is the number of tied values. Positive values of $Z_{M K}$ indicate increasing trends, while negative $Z_{M K}$ values indicate decreasing trends in the time series. When $Z_{M K}>Z_{1-\alpha / 2}$, the null hypothesis is rejected and a significant trend exists in the time series. $Z_{1-a / 2}$ is the critical value of $Z$ from the standard normal table, for 5\% significant level the value of $Z_{1-a / 2}$ is 1.96 [22].

In Figures 4-7 you can see the trends with the MKT method.

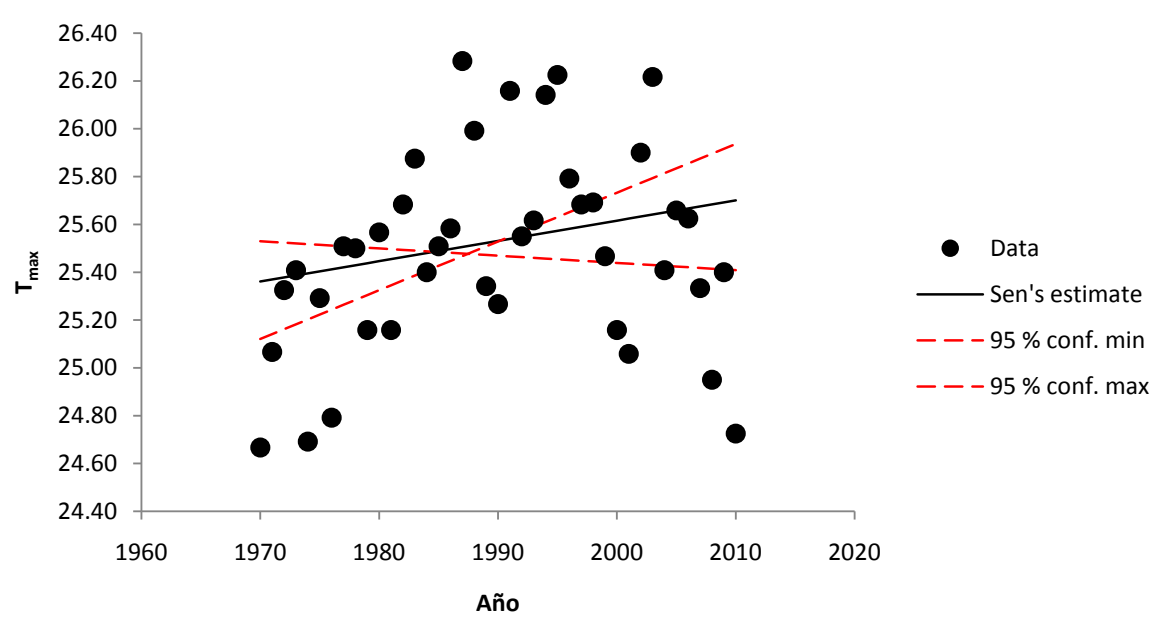

Figure 4. Comitan weather station trends for $t_{\max }$.

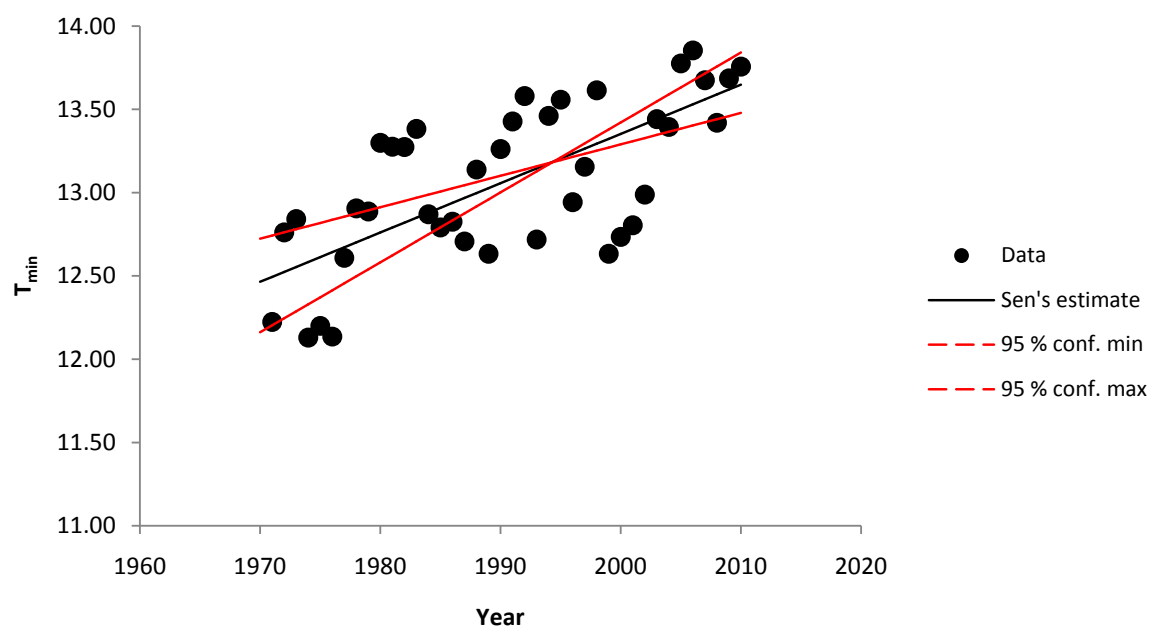

Figure 5. Comitan weather station trends for $t_{\text {min }}$. 


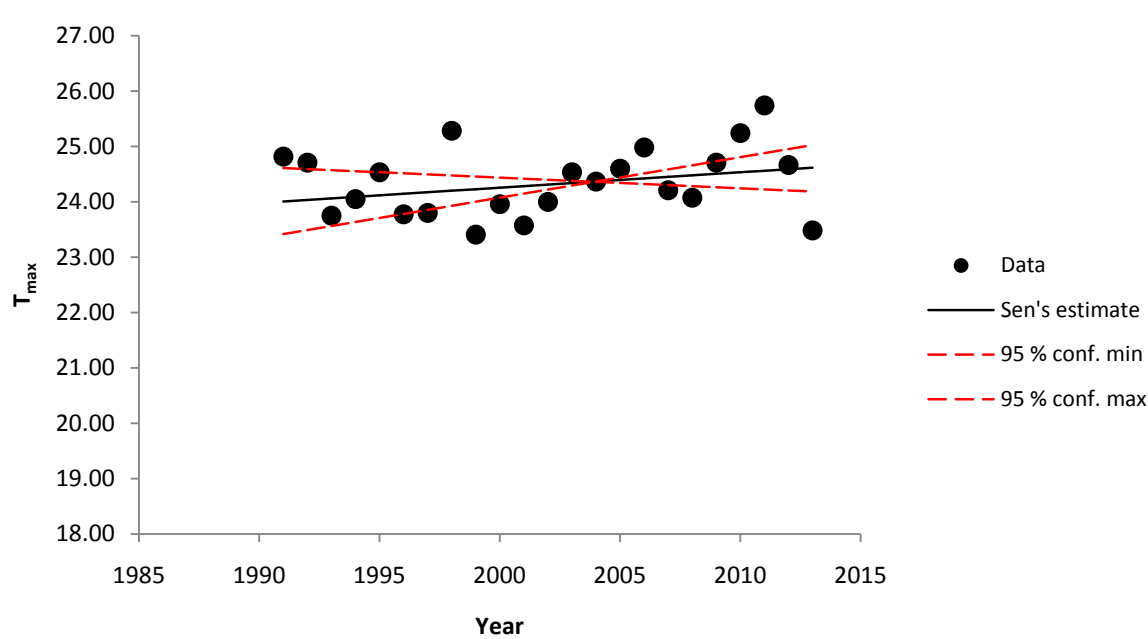

Figure 6. La Esperanza weather station trends for $t_{\max }$.

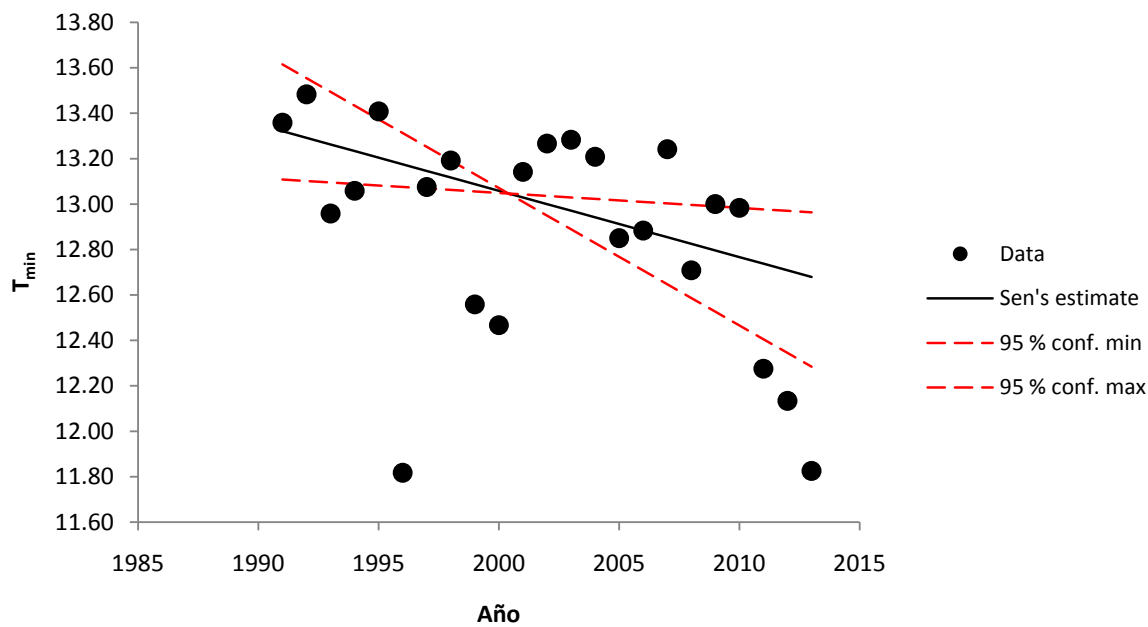

Figure 7. La Esperanza weather station trends for $t_{\min }$.

According to Figure 4 and Figure 5 a trend of temperature increase is observed at the Comitan weather station. The MKS trend test revealed an increase in the $t_{\max }$ and $t_{\min }$. While the $t_{\max }$ no statistically significant, the $t_{\min }$ is statistically significant. According to Figure 6 and Figure 7 a trend of temperature increase and decrease are observed at the La Esperanza weather station. The MKS trend test revealed an increase in the $t_{\max }$. While the $t_{\max }$ no statistically significant, the $t_{\min }$ is statistically significant. The time series of Comitan y La Esperanza weather stations were significant at the $5 \%$ significant level.

\section{Conclusion}

The maximum and minimum temperature series, $t_{\max }$ and $t_{\min }$, were studied for weather stations 07205 Comitan and 07374 La Esperanza located in the DTT 011 Margaritas-Comitan in the HR Grijalva-Usumacinta which have a registry of 54 and 30 years, respectively. Because the series had $2.07 \%$ and $19.04 \%$ of missing 
information, they were filled with the WS method. Homogeneity was analyzed with the SNHT method. Due to its heterogeneity, it was homogenized with climatol. The objective was to analyze the evidence of climate change in the Valle of Comitan with three methods: simple linear regression, Spearman's rho and Mann Kendall test were used. The Mann-Kendal test method confirmed the warming trend at the Comitan weather station for both variables with $Z_{M K}$ statistic values equal to 1.57 (statistically not significant) and 4.64 (statistically significant). A trend of temperature increase and decrease is observed at the La Esperanza weather station. The MKT trend revealed an increase in the $t_{\max }$ at $Z_{M K}=1.16$, nevertheless, this value is statistically not significant, while the Man Kendal test trend revealed a decrease in the main at $Z_{M K}=-2.27$ which is statistically significant. These results indicate that the warming trend in the Comitan weather station is produced by the heat islands, in a city of 150,000 inhabitants. While in the Esperanza weather station (in a field area), the trend is negative (the decrease of temperature), for a significance level $\alpha=0.05$.

\section{Acknowledgements}

María Concepción Villagran Alegria, Ricardo Fidel García Sánchez, José Enrique Ruiz Sarmiento and José Eduardo Solórzano Jiménez, student of the Faculty of Engineering of the Autonomous University of Chiapas, who carried out the depuration of the meteorological data, filled in the time series and supported this investigation by carry out the statistical studies. Special thanks to Michael J. Greces for translating this paper.

\section{Conflicts of Interest}

The authors declare no conflicts of interest regarding the publication of this paper.

\section{References}

[1] Rivera, O.S., Gómez, E.C., Vargas, I.C., Tapia, Z.A. and Guadarrama, C.F. (2011) Cambio Climático Global a través del tiempogeológico. Investigación Universitaria Multidisciplinaria. Año 10, nº10.

[2] Zamora, A.A. (2013) Primera reconstrucción paleo-climáticacuantitativa: Del polen de madriguera al clima del pasadoen un transecto altitudinal del Altiplano de Chile, Pozo Almonte-Salar del Huasco, Región de Tarapacá. Tesis de licenciatura. Carrera de Geografía. Universidad de Chile. Santiago de Chile.

[3] GEC (2013) Programa regional de desarrollo 2013-2018. Región XV Meseta Tojolabal Comiteca. Gobierno del Estado de Chiapas (GEC) Tuxtla Gutiérrez.

[4] SEMARNAT (2011) Estadísticasagrícolas de los distritos de temporal tecnificado. Añosagrícola 2010. Comisión Nacional del Agua. México, D.F.

[5] SEMAVIHN (2010) Programa de acción ante elcambioclimático del estado de Chiapas. Secretaría de Medio Ambiente, Vivienda e Historia Natural (SEMAVIHN) delGobierno de Estado de Chiapas. ConservaciónInternacional. Universidad de Ciencias y Artes de Chiapas. Tuxtla Gutiérrez, México. 
[6] Alonso, F.G. (2017) Índices de cambioclimáticoen la cuenca del Río Grande, Chiapas, México. Tecnología y Ciencias del Agua, 8, 137-143.

[7] OMM (2011) Guía de prácticasclimatológicas. OMM No. 100. Organización Meteorológica Mundial (OMM) Ginebra, Suiza.

[8] Renom, M. (2011) Principiosbásicos de las medicionesatmosféricas: Estaciones-m meteorológicas. Unidad de Ciencias de la Atmósfera de la Facultad de Ciencias de la Universidad de la República de Uruguay. Montevideo, Uruguay.

[9] Mundo-Molina, M. (2017) Análisis de los procesoscíclicos de enfriamientocalentamiento y anomalías de las temperaturasmáximas, media y mínimas de la estaciónmeteorológicas 07205 ubicadaen la mesetacomiteca de la RH GrijalvaUsumacinta, enelmarco de la inestabilidadclimática global. Capítulo del libro "La cuenca del Río Usumacinta desde la perspectiva del cambioclimático", Instituto Mexicano de Tecnología del Agua, Cuernavaca, Morelos, México.

[10] WMO (1989) Calculation of Monthly and Annual 30-Year Standard Normals. WMO/TD-No. 341, WCDP-No. 10, Ginebra, Suiza.

[11] Massetti, L. (2013) Analysis and Estimation of the Effects of Missing Values on the Calculation of Monthly Temperature Indices. Theoretical and Applied Climatology, 117, 511-519. https://doi.org/10.1007/s00704-013-1024-8

[12] Toro, T.A., Artega, R.R., Vázquez, P.M. and Ibañez, C.L. (2015) Relleno de series diarias de precipitación, temperaturamínima, máxima de la regiónnorte del UrabáAntioqueño. Revista Mexicana de Ciencias Agrícolas, 6, 577-588. https://doi.org/10.29312/remexca.v6i3.640

[13] Gamboa, C.R. (2015) Evaluación de modelosempíricos, matemáticos y redes neuronales para estimardarosfaltantesenestacionesmeteorológicasen México. Tesis de Maestría. Colegio de Postgraduados, Montecillo, Texcoco, Estado de México. 142 p.

[14] Elías, C.F. and Castellvi, S.F. (1996) Agroclimatología. Ed. Mundi Prensa, Madrid.

[15] Alexandersson, H. (1986) A Homogeneity Test Applied to Precipitation Data. Journal of Climatology, 6, 661-675. https://doi.org/10.1002/joc.3370060607

[16] Sahin, S. and Cigizoglu, K. (2010) Homogeneity Analysis of Turkish Meteorological Data Set. Hydrological Processes, 24, 981-992. https://doi.org/10.1002/joc.3370060607

[17] Guijarro, A.J. (2103) User's Guide to Climatology. State Meteorological Agency (AEMET), Balearics Islands Office, Spain.

[18] Dahmen, E. and Hall, M. (1990) Screening of Hydrological Data: Tests for Stationarity and Relative Consistency. Publication \#49, ILRI, The Netherlands, 58.

[19] Tonkaz, T., Çetin, M. and Kâzım, T. (2007) The Impact of Water Resources Development Projects on Water Vapor Pressure Trends in a Semi-Arid Region, Turkey. Climatic Change, 82, 195-209. https://doi.org/10.1007/s10584-006-9160-0

[20] Yue, S., Pilon, P. and Cavadias, G. (2002) Power of the Mann-Kendall and Spearman's Rho Tests for Detecting Monotonic Trends in Hydrological Series. Journal of Hydrology, 259, 254-271. https://doi.org/10.1016/S0022-1694(01)00594-7

[21] Martínez, R., Tuya, L., Pérez, A. and Cánovas, A. (2009) El coeficiente de correlación de los rangos de Spearman caracterización. Rev habanciencméd, La Habana, 8, 1-19.

[22] Mojtaba, S., Safar, M. and Majid, R. (2011) Trend Analysis in Reference Evapotranspiration Using Mann-Kendall and Spearman's Rho Tests in Arid Regions of Iran. Water Resources Management, 26, 211-224. https://doi.org/10.1007/s11269-011-9913-Z 
[23] Berger, A. (1986) Annual and Seasonal Climatic Variations the Northern Hemisphere and Europe during the Last Century. Annales Geophysicae, 4, 385-400.

[24] Mann, H.B. (1945) Nonparametric Tests against Trend. Econometrica, 13, 245-259. https://doi.org/10.2307/1907187

[25] Kendall, M.G. (1975) Rank Correlation Methods. Griffin, London.

[26] da Silva Alves, K. and Silva, R. (2016) Tendenciapluviométrica y concentraciónestacional de precipitaciónen la cuencahidrográfica del ríoMoxotó-Pernamcuco-Brasil. Revista Geográfica de América Central, 1, 295. https://doi.org/10.15359/rgac.58-1.12 